\title{
Algunos temas contrarreformistas de la pintura de El Greco
}

\author{
Francisco Javier Caballero Bernabé *
}

\begin{abstract}
RESUMEN ABSTRACT
Se comenta brevemente los temas que abarca la pintura de El Greco.

El estudio se centra en el tema religioso señalando las fuentes y el origen de los que proceden los distintos asuntos representados. Se analizan las imágenes según los Decretos del Concilio de Trento y su reflejo en la pintura del Cretense.

Se estudia la iconografía de algunos temas contrarreformistas pintados por El Greco relacionados con Cristo, la Virgen y los santos.

It is briefly commented the aspects which cover El Greco's paintings. The study is focused on the religious subject setting up the sources and the origins on which are based the different themes represented. The images are analysed in accordance with the Council of Tren Decrees and its reflection on the Cretan paintings.

It is studied the iconography from some Counter-Reform subjects painted by El Greco related to Christ, the Virgin, and saints.
\end{abstract}

\section{TEMAS DE LA PINTURA DE EL GRECO}

El Greco recoge a través de su pintura diversos temas: paisaje, mitológico, de género, retrato, religioso.

Algunos de los temas son poco frecuentes en la pintura española de finales del siglo XVI como los tres primeros señalados. Asi de los asuntos representados en estos temas por El Greco no existen pinturas de otros artistas españoles.

* Doctor en Historia del Arte. Universidad Complutense. 
En el caso de los retratos, el Cretense parece recorrer buena parte de la escala social tanto civil como eclesiástica.

En el mundo civil recoge a la mujer, aunque sea a través de un solo ejemplar "Mujer joven"; los nobles "Caballero de la mano en el pecho", "Caballero de la Casa de Leiva"...; los militares "Julián Romero -el de las Azañas-y S. Luis»; los artistas "Jorge Manuel Theotocopuli», y los profesionales que hoy llamariamos liberales "Doctor Rodrigo de la Fuente", "Jerónimo de Cevallos".

El mundo eclesiástico abarca religiosos «Fray Félix Paravicino», «Fraile trinitario", "Fraile dominico o trinitario"; sacerdotes "Antonio de Covarrubias", "Canónigo Bosio"; obispos "Diego de Covarrubias"; cardenales "Cardenal Juan de Tavera", e inquisidores "Cardenal Niño de Guevara».

En este ámbito del retrato no aparecen seres de la escala social más baja: artesanos, campesinos, mendigos... Aunque ya existiesen retratos de personajes de procedencia social similar, caso de los bufones.

No conservamos, ni sabemos que pintase bodegones, aunque fue coetáneo y vecino de un artista tan extraordinario como Sánchez Cotán.

Los paisajes eran, también, poco frecuentes.

Estos géneros se estaban abriendo paso en la pintura y en pocos años ocuparian a los pinceles más conocidos de toda la Historia del Arte.

Estos temas (paisaje, género, mitológico y los retratos) parecen estar destinados a un público muy concreto, "selecto": aristocracia, hombres de cultura o de posición económica holgada e instituciones. En la mayoría de los casos son cuadros destinados a adornar espacios cerrados y de acceso restringido, es decir para disfrute de sus propietarios. De este conjunto algunos constituyen una excepción como el retrato del "Cardenal Juan de Tavera», pues trata de recordar al fundador del Hospital de Afuera de Toledo.

En la pintura religiosa de El Greco, la más abundante de la conservada, encontramos, en origen, conjuntos en instituciones (Sto. Domingo el Antiguo, Colegio de Da. María de Aragón, Hospital Tavera, Hospital de la Caridad ...) o en particulares (Capilla de S. José, Apostolado de la catedral de Toledo) '.

También encontramos obras aisladas, de pequeño o mediano tamaño, cuya procedencia fueron particulares, no siempre religiosos o sacerdotes y cuyo tema es devocional. En ocasiones no conocemos bien la relación entre

Caballero, F.J., "Nuevas aportaciones documentales sobre la obra de E.l Greco». Goya, 226. En.-Feb., 1992, págs. 222-224. 
el tema y el autor del encargo. Estos cuadros debieron estar colocados en capillas funerarias "Crucifixión con dos donantes"; en casas «S. Andrés y $\mathrm{S}$. Francisco de Asis" ". Algunos incorporan a los donantes como el citado de la Crucifixión y el de «Julián Romero -el de las Azañas- y S. Luis».

\section{PROCEDENCIA DE LOS TEMAS RELIGIOSOS}

\section{Fuentes Canónicas:}

- Los Evangelios: Temas de Cristo («Adoración de los pastores», "Bautismo", Crucifixión, "El Expolio", "Expulsión de los mercaderes del Templo», “Natividad», "Oración en el Huerto», “Resurrección»). Temas de la Virgen («Anunciación», "Sagrada Familia», "Visitación»). San Pedro ("Lágrimas de S. Pedro", "S. Pedro y S. Pablo"). San Juan Bautista ("S. Juan Bautista», "S. Juan Evangelista y S. Juan Bautista»).

- Hechos de los Apóstoles 2, 1-4: “Pentecostés".

- Carta de S. Pablo a los Filipenses 2,10: "Adoración del Nombre de Jesús".

- Apocalipsis 6, 9-11: «El Quinto sello del Apocalipsis».

\section{La tradición de la Iglesia:}

Algunos personajes aparecen citados en las fuentes canónicas: Apóstoles, Sta. María Magdalena, S. Pablo, S. Lucas, S. Andrés, Santiago el Mayor, S. Juan Evangelista. De muchos las noticias que tenemos son vagas y confusas, mezclándose los hechos históricos con las leyendas procedentes de diversas épocas y diferentes lugares. En ellas se basan la mayoria de los atributos que portan y que suelen hacer referencia a la forma de martirio: S. Pablo, la espada; S. Andrés, la cruz en aspa, ...; a hechos relacionados con el mismo: S. Bartolomé, el demonio encadenado; una afición: S. Lucas, que siendo médico se le atribuye haber pintado a la Virgen; hechos atribuidos a su vida: "Sta. María Magdalena», quien pasa por haber sido una mujer pecadora y posteriormente una eremita; "Santiago el Mayor, peregrino", del que se afirma que estuvo en España predicando el Evangelio.

WETHEY, H.E., El Greco y su escuela. T.II. Madrid, Guadarrama, 1967, pág. 214. 
Temas como la «Inmaculada Concepción» y la «Coronación de la Virgen" se apoyan además en escritos de Padres de la Iglesia, fuente que también podría servir para la «Despedida de Cristo de la Virgen», la "Santísima Trinidad", el "Calvario con ángeles", donde la presencia de éstos entronca con el bizantinismo, y la «Piedad».

\section{Los Evangelios Apócrifos:}

El hecho puede estar referido o sugerido en los Evangelios Canónicos, este es el caso de los "Desposorios de la Virgen", del cual El Greco realiza una versión libre, pues presenta a $S$. José joven, frente a los textos que le describen como una persona de mayor edad.

Temas como la "Santa Faz" y la "Verónica con la Sta. Faz" se inspiran concretamente en los Escritos complementarios, dentro del ciclo de Pilato, y entre ellos el de la "Muerte de Pilato". La "Asunción" basada en la tradición de la Iglesia y en los Evangelios Apócrifos, Libro de Juan, arzobispo de Tesalónica, de fecha incierta.

\section{La devoción:}

"Cristo con la cruz", "Cabeza de Cristo", la "Virgen de la leche".

En este apartado hay que incluir a "S. José y el Niño Jesús", escena de la cual las referencias son escasas en los Evangelios Canónicos y algo más numerosas en los Apócrifos. El Concilio de Trento revalorizó el tema. El fundador de la capilla, Martín Ramírez, lo indicó expresamente tal vez por influencia de Sta. Teresa con la que tuvo amistad, ya que esta Santa nombró a S. José patrón de todas sus fundaciones.

Las obras relacionadas con los santos de la Edad Antigua (S. Agustín, Sta. Catalina de Alejandría, S. Jerónimo, S. Lorenzo, S. Martín, S. Mauricio, S. Sebastián) y de la Edad Media (S. Antonio de Padua, S. Benito, S. Bernardino de Siena, S. Bernardo, Sto. Domingo de Guzmán, $S$. Francisco de Asís, S. Ildefonso, S. Jacinto, S. Luis), tienen también un origen diverso: La devoción particular de los promotores de la obra, caso del tema de $\mathrm{S}$. Francisco de Asís de tantas versiones y ejemplares como se realizaron, o el de $\mathrm{S}$. Jerónimo, $\mathrm{S}$. Martín. Los encargos específicos de órdenes religiosas ( $\mathrm{S}$. Benito, S. Bernardo) o de la corona (S. Mauricio).

No encontramos cuadros que hagan referencia a santos de los siglos XV, XVI o principios del XVII. 
Hechos históricos relacionados con esa época:

La "Aparición de la Virgen con el Niño a S. Jacinto" canonizado en 1594. "Alegoría de la Orden Camaldulense" que fue introducida en España en 1597 por Fr. Juan de Castañiz. "Adoración del Nombre de Jesús» que hace referencia a la batalla de Lepanto, 1571. «El Entierro del Sr. de Orgaz" que hace referencia a un hecho que aconteció en 1323 , según la tradición, y que la iglesia de Sto. Tomé manda representar, en 1586, para recordar a los de la villa de Orgaz que deben pagar a esta iglesia las rentas dejadas por don Gonzalo Ruiz de Toledo. "Martirio de S. Mauricio y la Legión Tebana" el tema hace referencia a un hecho acontecido en la época del emperador Diocleciano, Felipe II manda hacer el cuadro en 1580 para conmemorar la llegada a El Escorial de sus reliquias.

\section{LAS IMAGENES SEGÚN EL CONCILIO DE TRENTO Y EL GRECO}

En la última sesión del Concilio de Trento (1563) se adoptan decretos referentes al culto y la veneración de los santos, se indican los postulados que deben seguir las creaciones artísticas que representan a las Personas Divinas, la Virgen y los santos.

!.a Iglesia católica al fijar la doctrina sobre la Virgen y los santos se opone a las tesis doctrinales de los protestantes quienes niegan que fuesen dignos de un trato singular, pues simplemente son ejemplos estimulantes de la fe. Consecuentemente su culto y representación pierden sentido.

La Contrarreforma consiente el uso de las imágenes por diversas razones:

a) Se sigue una tradición de la Iglesia continua a lo largo de la Edad Antigua y la Edad Media, que sólo en momentos puntuales ha sufrido interrupciones (Querella Iconoclasta).

b) La Virgen y los santos son considerados intercesores ante Dios por los hombres «...que instruya diligentemente a los fieles en primer lugar sobre la intercesión de los santos, ... y el uso legítimo de sus imágenes, enseñándoles que los santos, reinantes junto con Jesucristo, ofrecen sus oraciones a Dios en favor de los hombres» ${ }^{3}$.

Garriga, J., Renacimiento en Europa. Col. Fuentes y Documentos para la Ha. del Arte, IV Barcelona, 1983, pág. 346. 
c) Los santos son hombres y mujeres que han imitado a Cristo. Su recuerdo nos lleva a la fuente de su inspiración, al modelo que todo cristiano debe imitar.

d) Las imágenes se constituyen en biblias ilustradas para los que no saben leer. Por este camino los cristianos aprenden o recuerdan los principios dogmáticos que deben creer y practicar "Enseñen también con diligencia los obispos que, a través de las historias de los misterios de nuestra redención expresadas en pinturas y otras representaciones, el pueblo es ilustrado y confirmado en la conmemoración y en la asidua veneración de los artículos de la fe» ${ }^{4}$.

e) La veneración que se tributa a las imágenes no es al objeto en sí, sino a lo que representan, evitando de esta manera la idolatría "porque el honor que se tributa a las imágenes va dirigido a los prototipos que ellas representan..." 5 .

El Concilio de Trento señala dónde y cómo deben representarse las imágenes. Estas se deben colocar en lugares propicios para el culto o la veneración, principalmente en los templos. Deben conservarse, es decir tienen que cuidarse y repararse o sustituirse cuando sufran deterioros acusados "Enseñen además que las imágenes de Jesucristo, de la Virgen Madre de Dios y de los demás santos deben se expuestas y conservadas, principalmente en los templos y que ha de tributárseles el honor y la veneración debidos» 6 .

Evitándose toda superstición en cuanto a las imágenes, así como la lascivia y belleza provocativa en la representación «En adelante sea erradicada toda supertición en la invocación de los santos, en la veneración de sus reliquias y en el uso sagrado de sus imágenes, ... sea evitada, en fin, toda lascivia, de modo que no se pinten ni adornen imágenes de belleza provocativa ..." ${ }^{7}$.

En lo referente a las imágenes por "lascivia" se entiende todo tipo de gestos que las mismas adopten. Por «belleza provocativa» toda sensualidad que suscite pensamientos o deseos impuros o impropios de lo representado.

En cuanto a las fuentes iconográficas llama la atención en esta época contrarreformista, la existencia de fuentes no canónicas como los Evangelios Apócrifos para temas como los señalados más arriba. Esto en principio es una contradicción, ya que el Concilio señala expresamente cuales son los 
textos referenciales para los católicos, aunque deja una puerta abierta al hablar de la "tradición", que no solo se plasmaría en la pintura y escultura, sino en la literatura (sermones, villancicos, comentarios de textos sagrados o piadosos...). Campos que a su vez están relacionados entre sí, pues ésta última describe imágenes y escenas que las primeras representan en ocasiones.

Muchos temas pintados por El Greco tienen relación directa o indirecta con la Contrarreforma.

Los postulados generales emanados del Concilio de Trento se cumplen en la pintura del cretense, pues éstas se inspiran tanto en textos canónicos como no canónicos, pero aceptados generalmente por asumir la tradición de la Iglesia. De manera que son escasos los casos conocidos en los cuales El Greco tuvo problemas el "Expolio» y la "Virgen de la Caridad». En el primero, por la presencia de las tres Marías, aunque hay que atender también a la cuestión de la tasación para comprender globalmente la situación. En el segundo, el conflicto económico también existió y tal vez aquí si pueda entenderse el calificativo de "irreverente" que se dio a los cuellos con que se adornaban los caballeros. En ambos casos el acuerdo fue positivo y no se tuvo que borrar esa parte del cuadro, lo que demuestra que las discrepancias eran un motivo secundario que encubrían otros aspectos no religiosos. En el caso del "Entierro del Sr. de Orgaz" dada la complejidad y la infrecuencia del tema se solicitó el correspondiente permiso al arzobispo de Toledo y éste lo concedío.

La Virgen y los santos son interpretados como intercesores, ejemplos de ello serían la parte superior del "Entierro del Señor de Orgaz" y $S$. Luis en "Julián Romero -el de las Azañas-y S. Luis".

Las escenas tienen un sentido didáctico, pues ninguno de los temas tratados por El Greco tiene una interpretación ambigua o poco clara. Además tienen carácter narrativo, es decir cuentan hechos concretos y fácilmente reconocibles por personas analfabetas.

Ninguna de las pinturas muestra elementos accesorios o gestos que sugieran superstición, lascivia o belleza provocativa ("Sta. Ma. Magdalena», «S. Sebastían», la "Expulsión de los mercaderes del Templo", la "Piedad» ...). Incluso hasta la belleza está ausente en muchos rostros y cuerpos ${ }^{8}$. De manera que no se siente el espectador atraido por el aspecto externo de las imágenes (belleza, dramatismo...). Se necesita una sensibilidad especial

"Caballero, F.J., "Algunos aspectos de la figura humana en la pintura de El Greco". Espacio, Tiempo y Forma, rev. de la Facultad de Geografía e Historia de la UNED, VII, 8, 1995, págs. 39-53. 
de cierto nivel intelectual para aceptar las fórmulas manieristas (canon, deformaciones anatómicas...) y los atrevimientos técnicos (color, luz...) y buscar más allá de lo que se ve, es decir para penetrar en la riqueza que encierra la iconografía.

Todos los temas religiosos, de la pintura de EI Greco, en general tienen carácter contrarreformista, pues en el protestantismo no está permitido el culto a los santos y a la Virgen. Por lo tanto la simple representación de los mismos supone un seguimiento de los principios emanados de Trento.

\section{ALGUNOS TEMAS CONTRARREFORMISTAS DE EL GRECO}

\section{La Expulsión de los Mercaderes del Templo}

Existen varias versiones en Nueva York, Londres (fig. 1), Madrid...

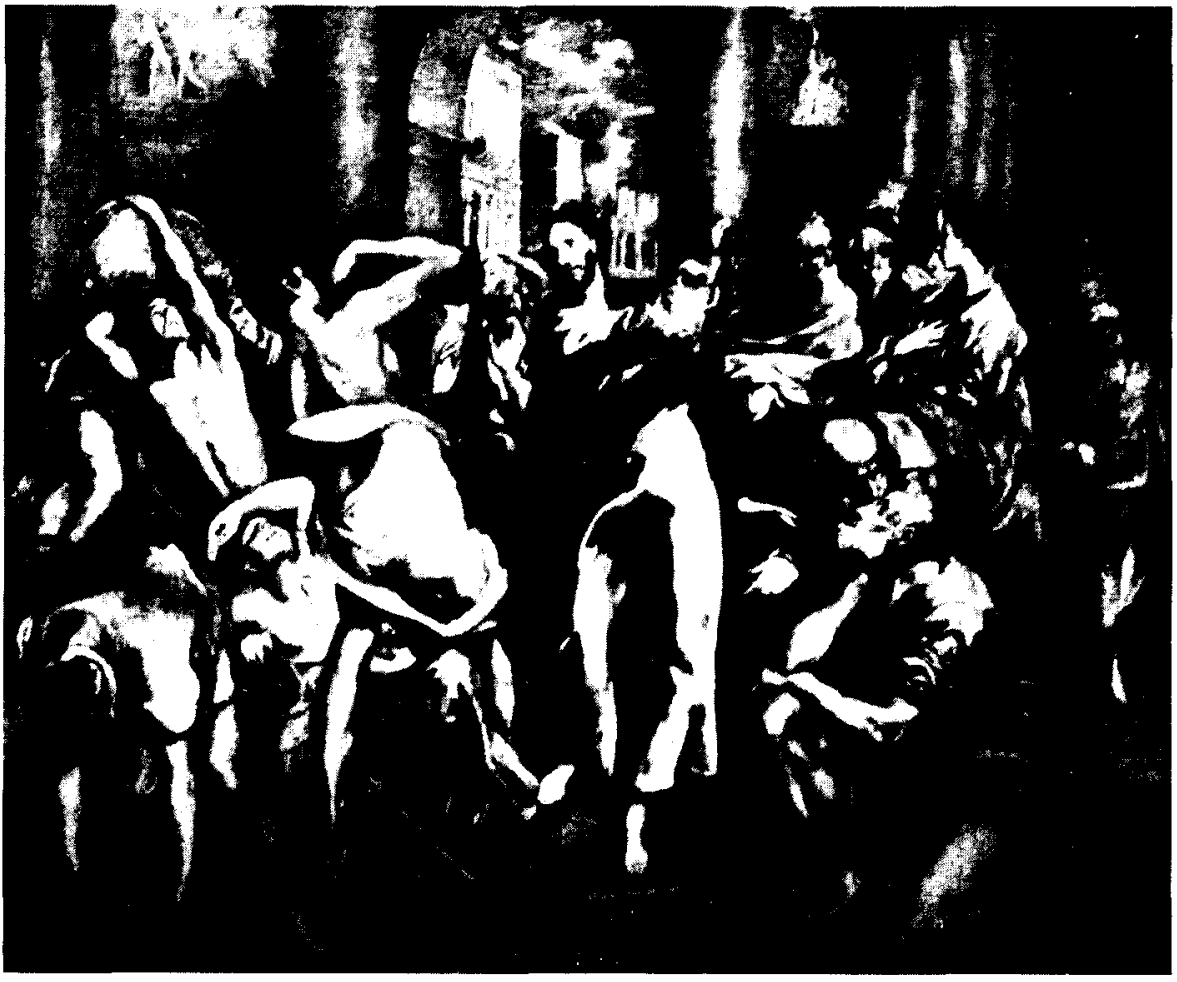

Fig. 1. La "Expulsión de los mercaderes del Templo" National Gallery, Londres. 
La obra se inspira en los cuatro evangelios: los tres sinópticos (Mt. 21, 12-13; Mc. 11, 15-17; Lc. 19, 45-46) apenas se diferencian y no entran en detalles, situando el acontecimiento al final de la vida pública de Jesucristo. San Juan $(2,13-16)$ la coloca al principio de la predicación, el texto es ligeramente más amplio y con algunos detalles.

Jerusalén y su templo han dado paso a diferentes escenarios ideales contemporáneos del autor.

El Sacrificio de Isaac y la Expulsión de Adán y Eva del Paraiso, que simbolizan a Cristo y la Purificación del Templo que es imagen de Cristo también, de manera que toda persona en pecado no puede estar en lugar sagrado, ya sea el paraiso terrenal, el Templo de Jerusalén, la vida eterna. El tema de la "Expulsión de los mercaderes del Templo" fue utilizado por papas trentinos como Paulo IV, Pío IV y Gregorio XIII, en medallas conmemorativas de sus pontificados ${ }^{9}$.

El tema es alusivo a la Reforma protestante y a los judíos. Adán y Eva y los mercaderes, simbolizan a ambos. La actitud del ángel y de Cristo, similar, es el destino final que les espera, la expulsión de la vida eterna según el Concilio de Trento, salvo que adopten la actitud de Isaac que se somete a la autoridad de Abraham, es decir de Cristo que acepta la voluntad del Padre. De la misma manera el protestante y el judío deben someterse y acogerse a la Iglesia católica única vía a través de la cual se obtiene la salvación. La Anunciación tendría este mismo significado, María dice si al plan de Dios y permanece fiel y es premiada con la virginidad.

\section{El Bautismo}

Existen versiones en Madrid (fig. 2) y Toledo.

Las fuentes son los Evangelios sinópticos (Mt 3, 13-17; Mc 1, 9-11; Lc $3,21-22)$. El fragmento es similar en los tres autores, discrepando sobre el momento exacto en el que el Espíritu Santo desciende en forma de paloma. Recoge el momento en el cual por primera vez aparece la Santísima Trinidad, dogma de la doctrina católica.

Cristo, después de resucitado, instituye este sacramento (Mt 28,19 ) «id, pues; enseñad a todas las gentes, bautizándolas en el nombre del

WETHEY, H.E., Op. cit., p.81. 


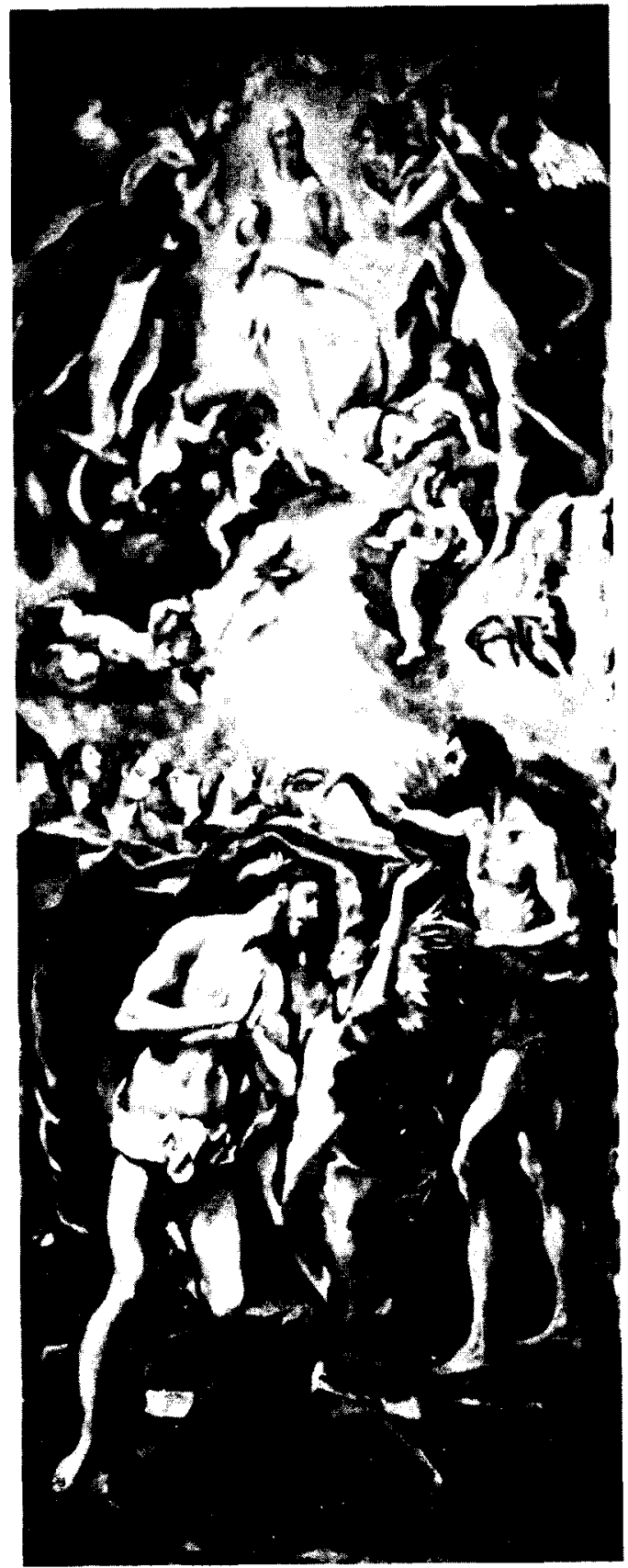

Fig. 2. El "Bautismo de Cristo" M. del Frado, Madrid. 
Padre, del Hijo y del Espíritu Santo". Cristo señala a la Santísima Trinidad, de manera que en el bautismo de cada cristiano se recuerda el suyo propio.

El bautismo es uno de los dos sacramentos aceptados por la Reforma protestante luterana, pero cambian el rito. Estos siguen la manera de Cristo, es decir es sumergido, significado de la palabra bautizar. En el protestantismo, el bautismo es signo de una nueva alianza, de haber sido admitido en la Iglesia visible en la tierra, supone estar lavado por la sangre redentora de Cristo, aunque no es garantía de predestinación, ni necesario para la salvación eterna, ni estirpa la raíz del pecado.

La Iglesia católica lo reafirma en el Concilio de Trento, fijando las palabras de Cristo en el texto de $\mathrm{S}$. Mateo y vertiendo tres veces agua sobre la cabeza del neófito, de igual valor que la inmersión.

Para los católicos el bautismo borra el pecado original y los demás pecados que quedan sumergidos en el agua y se nace a una nueva vida en Cristo que prefigura la resurrección final. Para la Iglesia católica es el único camino de salvación.

La humillación de Cristo delante de $\mathrm{S}$. Juan Bautista según el Evangelio de $S$. Mateo $(3,15)$ «Pero Jesús le respondió: Déjame hacer ahora, pues conviene que cumplamos toda justicia. Entonces Juan se lo permitió" parece estar relacionada con las mismas palabras que Cristo pronuncia en otro momento de su vida "porque el que se ensalza será humillado y el que se humilla será ensalzado" (LC. 14, 11). Siendo el propio Cristo con su conducta el modelo a seguir, pese a que El no haya pecado. También hace referencia al arrepentimiento necesario para recibir el perdón de los pecados.

El hacha, que aparece junto al zurrón, guarda relación con los pasajes de $S$. Mateo $(3,10)$ y S. Lucas $(3,9)$, que son similares "Ya el hacha está puesta a la raíz del árbol; todo árbol que no dé buen fruto será cortado y arrojado al fuego", lo que invita al arrepentimiento como único medio para recibir el bautismo, el agua que borra el pecado, por lo tanto cumple la función del sacramento de la penitencia, lo cual refuerza el sentido contrarreformista de la interpretación, ya que este último sacramento es negado por el protestantismo. 


\section{La Inmaculada Concepción}

Hay ejemplares en Toledo (fig. 3) y Madrid.

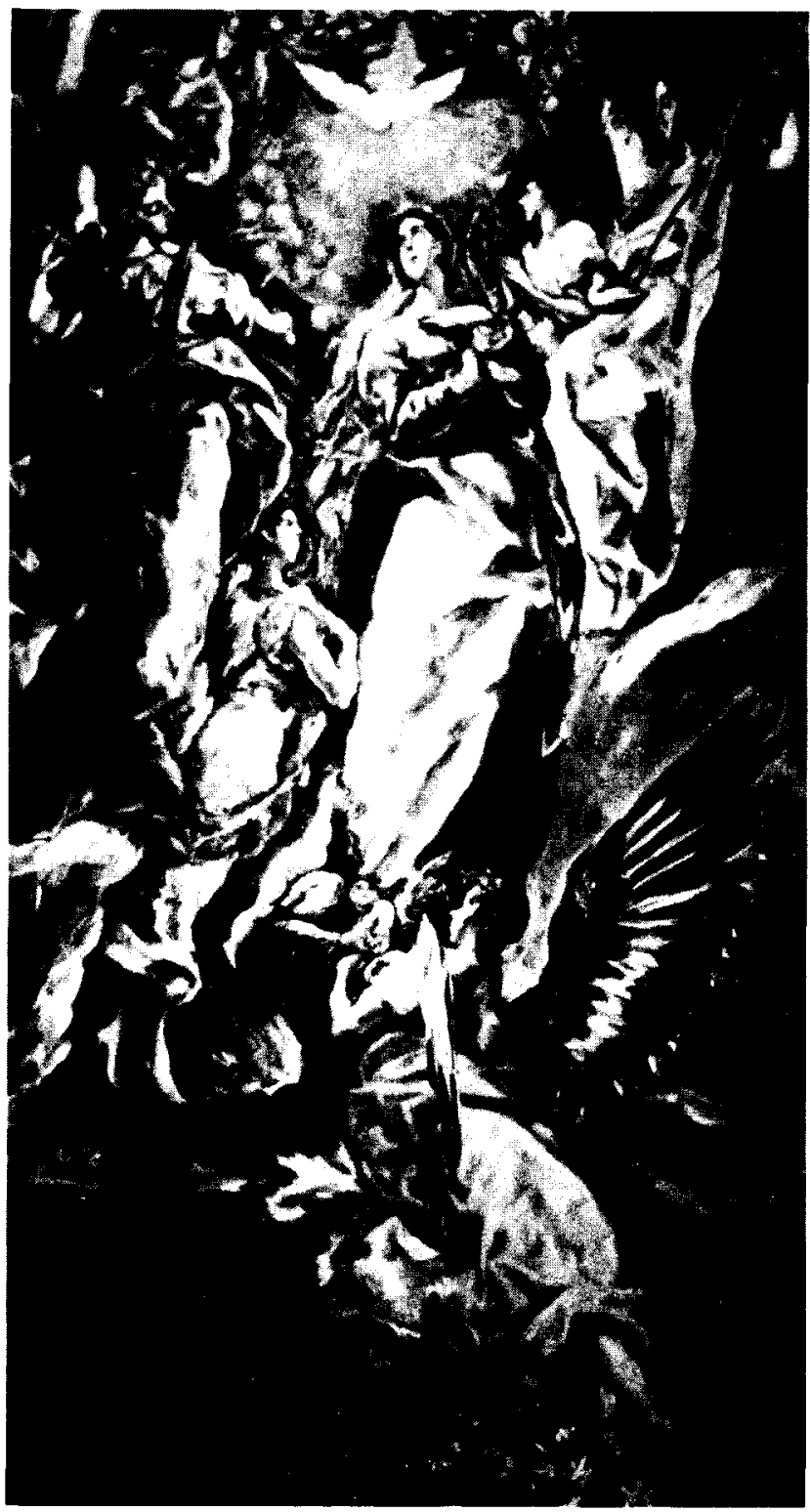

Fig. 3. La "Inmaculada Concepción" M. de Sta. Cruz, Toledo. 
La fuente hay que buscarla en los Padres de la Iglesia y en la tradición. El misterio de la Inmaculada Concepción fue fomentado especialmente en los países católicos por el Concilio de Trento, tras la aparición del protestantismo.

Sus símbolos se encontraban a comienzos del siglo XVI incluidos en el Breviario de Grimani ${ }^{10}$.

La postura de los protestantes es rechazar la virginidad de María, aunque por su maternidad sin concurso humano es signo de la acción especial de Dios y contribuye a la salvación del hombre.

La Iglesia católica no define en Trento el dogma (sería en el siglo XIX), sin embargo existe en países europeos, basado en la tradición y en los escritos de numerosos autores y santos, una sensibilidad especial hacia este tema. Este es el caso de España donde este dogma se juraba defenderlo por parte de los doctores universitarios. No debe extrañar que sea aquí donde se hagan representaciones sobre el tema tanto a nivel particular como en retablo.

\section{La Asunción}

Hay un ejemplar en Chicago procedente del convento de Sto. Domingo el Antiguo de Toledo (fig. 4).

El tema está basado en la tradición de la Iglesia y en los Evangelios apócrifos, Libro de Juan, arzobispo de Tesalónica ". Estos textos de fecha incierta sirvieron en la Edad Media de lectura edificante. Narra como el alma de la Virgen es transportada por el arcángel S. Miguel, la blancura tan extraordinaria que tenia, muy superior al sol y como al abrir la sepultura estaba vacia. También en la Narración del Pseudo José de Arimatea ${ }^{12}$ los discípulos discuten y al abrir el sepulcro se encuentran que está vacio. También en los escritos de numerosos autores.

Los protestantes no señalan nada especial respecto a este hecho, aunque es de suponer una negación implícita al negar a la Virgen el papel singular que desempeña en la Iglesia católica. Por otro lado ésta no definió

\footnotetext{
10 Stratron, S., “La Inmaculada Concepción en el arte español». Cuadernos de Arte e Iconografia I, 2, 1988, pág. 46.

XII, pág. 637; XIV, p.644. B.A.C., Madrid, 1963.

12 XVIII, pág. 655. B.A.C., Madrid, 1963.
} 


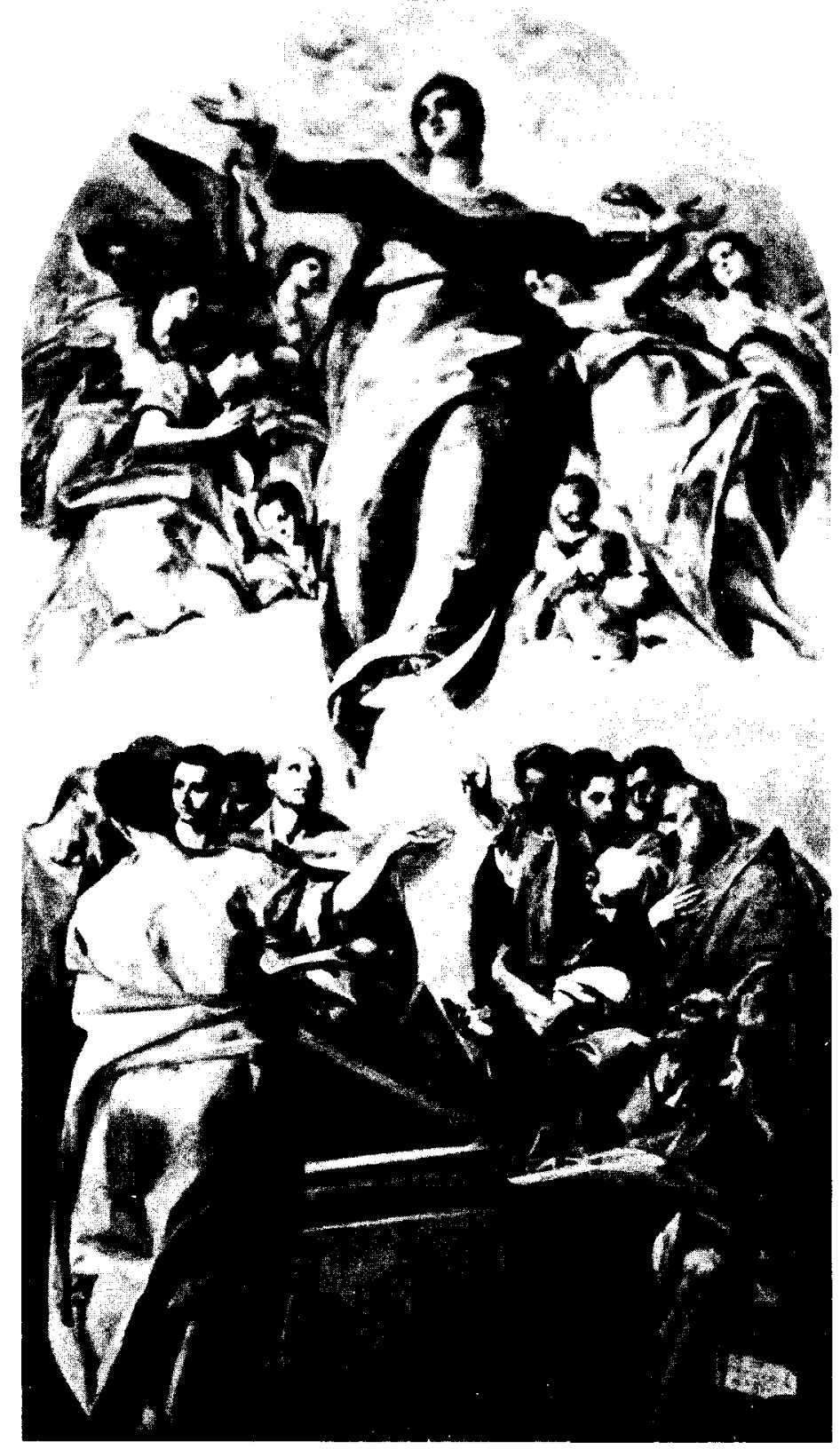

Fig. 4. La "Asunción de la Virgen" Art. Institute, Chicago. 
en el Concilio de Trento este dogma (sería en el siglo $x x$ ). Esta tradición es $\tan$ fuerte que obras con este tema aparecen en numerosas iglesias incluso después del Concilio de Trento.

\section{La Coronación de la Virgen}

Se conservan ejemplares en Illescas (Toledo) (fig. 5) y Madrid.

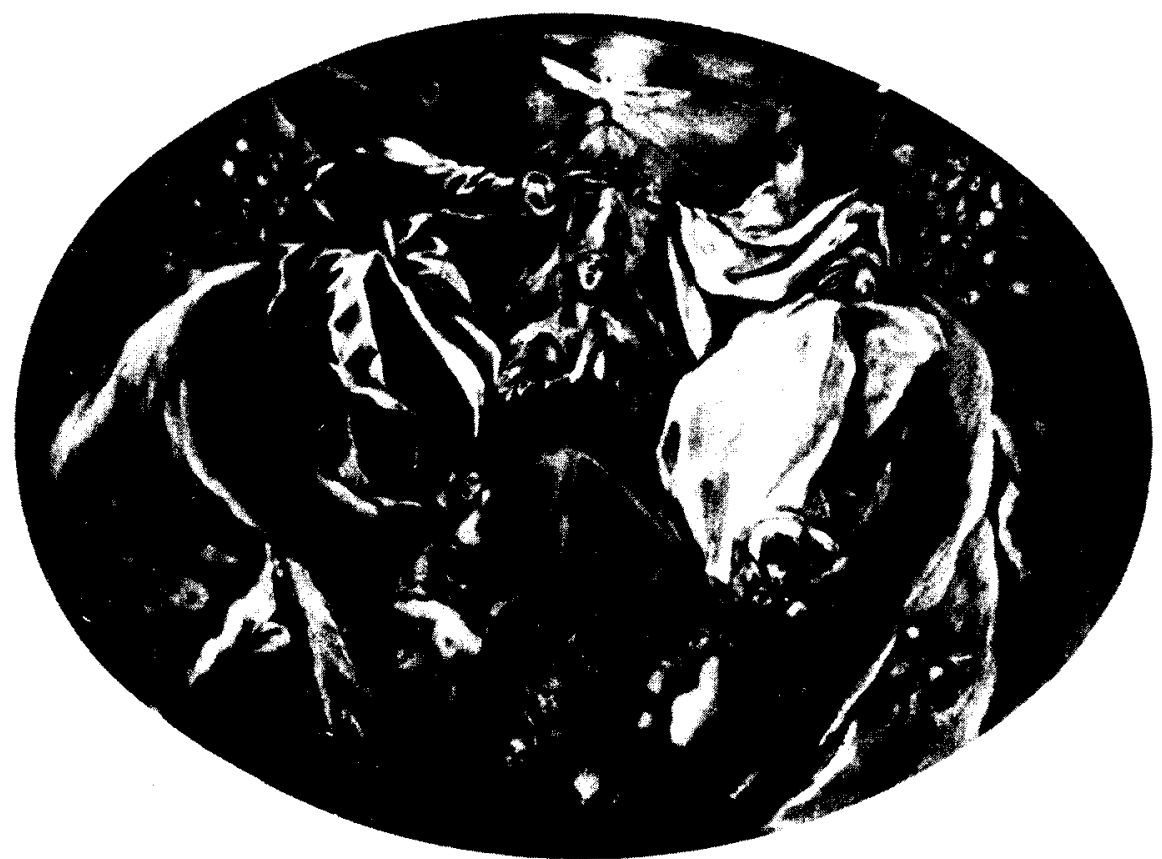

Fig. 5. La "Coronación de la Virgen» Hospital de la Caridad, Illescas (Toledo).

La fuente iconográfica hay que buscarla en la tradición de la Iglesia y los Santos Padres. Stratton señala que está incluida en el Tratado de Molanus ${ }^{13}$.

La Reforma protestante rechaza el tema por la misma razón que los anteriores.

13 Op. cit., pág. 44. 
La Iglesia católica lo acepta aunque en la época del Concilio de Trento no se hubiesen establecido los dogmas referentes a los temas anteriores. La Coronación de la Virgen como reina del cielo supone aceptar todos los atributos que la tradición otorga a María: Virgen, Madre de Dios, intercesora por la Humanidad, Reina de los santos, y del cielo,... En las letanías del Santo Rosario ya aparece con este título.

Hay que recordar que a raíz de la batalla de Lepanto (1571) el Rosario se convierte en oración "oficial» de la Iglesia.

Se la representa con corona en los temas de «Totta pulchra» del siglo XVI y en numerosas versiones de la Inmaculada Concepción antes de que se fije el modelo definitivo.

\section{La Virgen de la Caridad}

Un ejemplar en Illescas (Toledo) (fig. 6).

Se inspira en modelos de los siglos $x v$ y $x v i$ en los cuales la Virgen aparece como intercesora o protectora, Virgen de la Misericordia. Este último caso es el más próximo al representado en este tema.

Aquí se aunan dos aspectos que no tienen especial significado en el protestantismo: la Virgen y la Caridad. Caso contrario del Concilio de Trento que los ensalza, precisamente para contestar las posturas de los reformistas.

El lugar en el que se ubica el cuadro, un hospital, pone de manifiesto que la virtud de la caridad es la primada de las tres virtudes.

De qué servirian aquí la fe y la esperanza sin el consuelo de la humanidad que haga más llevadera la vida y cuanto en ella ocurre y especialmente en un lugar de enfermedad y sufrimiento. La fe y la esperanza son soportes psicológicos para los seres humanos, pero la caridad es un apoyo que afecta además a lo físico, por ello es más completa. También es más amplia, no distingue entre creyentes y no creyentes. De las tres es la única que permanece en la otra vida y la que nutre a la fe y la esperanza, según $S$. Pablo en la Primera Carta a los Corintios $(13,13)$. Se contrapone en este sentido a la fe, propuesta por los protestantes como la primada y base de la salvación. Estos valoran más el creer que el obrar. 


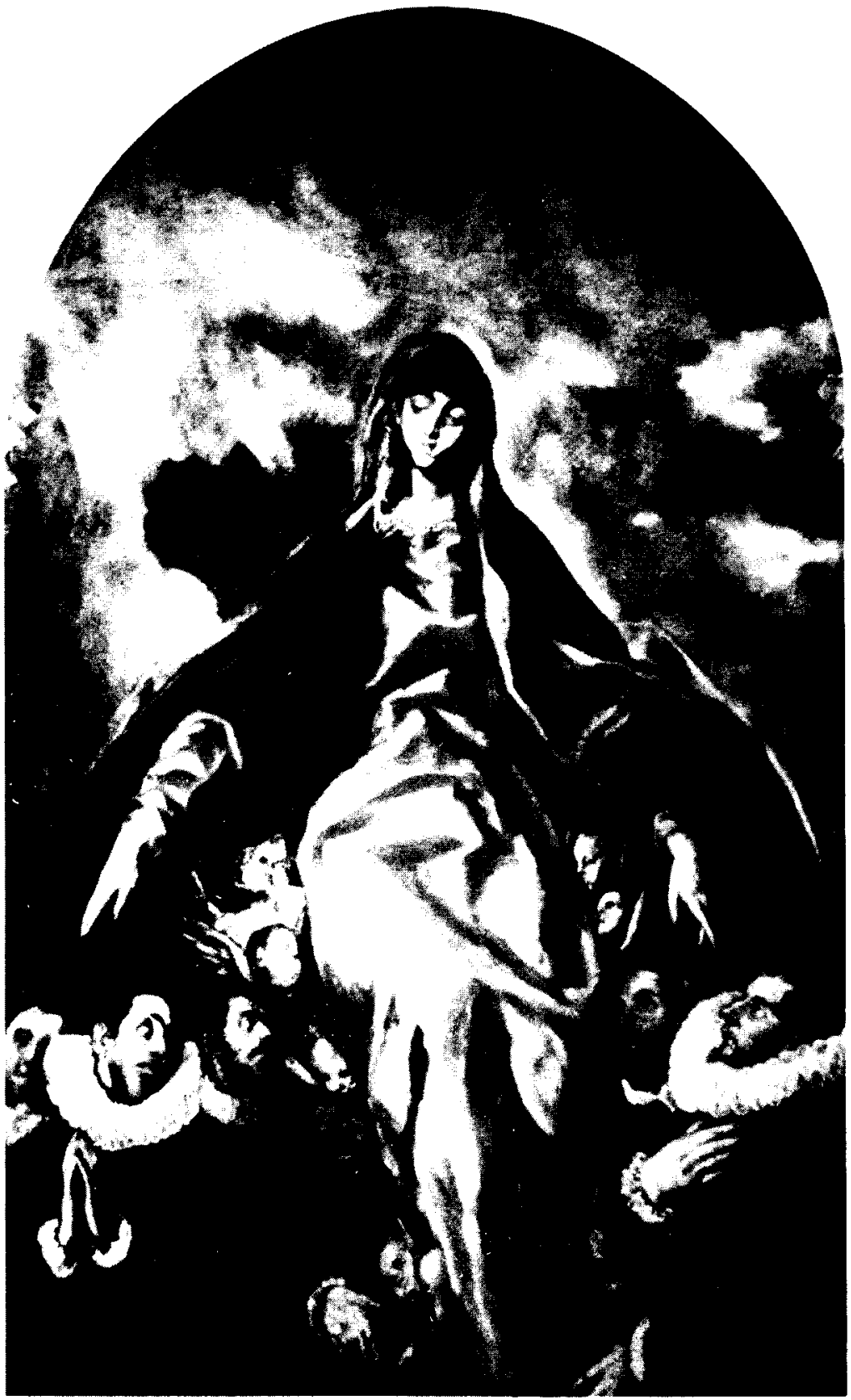

Fig. 6. La "Virgen de la Caridad" Hospital de la Caridad, Illescas (Toledo). 


\section{San Ildefonso}

Existen varias escenas relacionadas con este Santo. "S. Ildefonso escribiendo» en Illescas (Toledo) (fig. 7); “S. Ildefonso de pie» en El Escorial (Madrid).

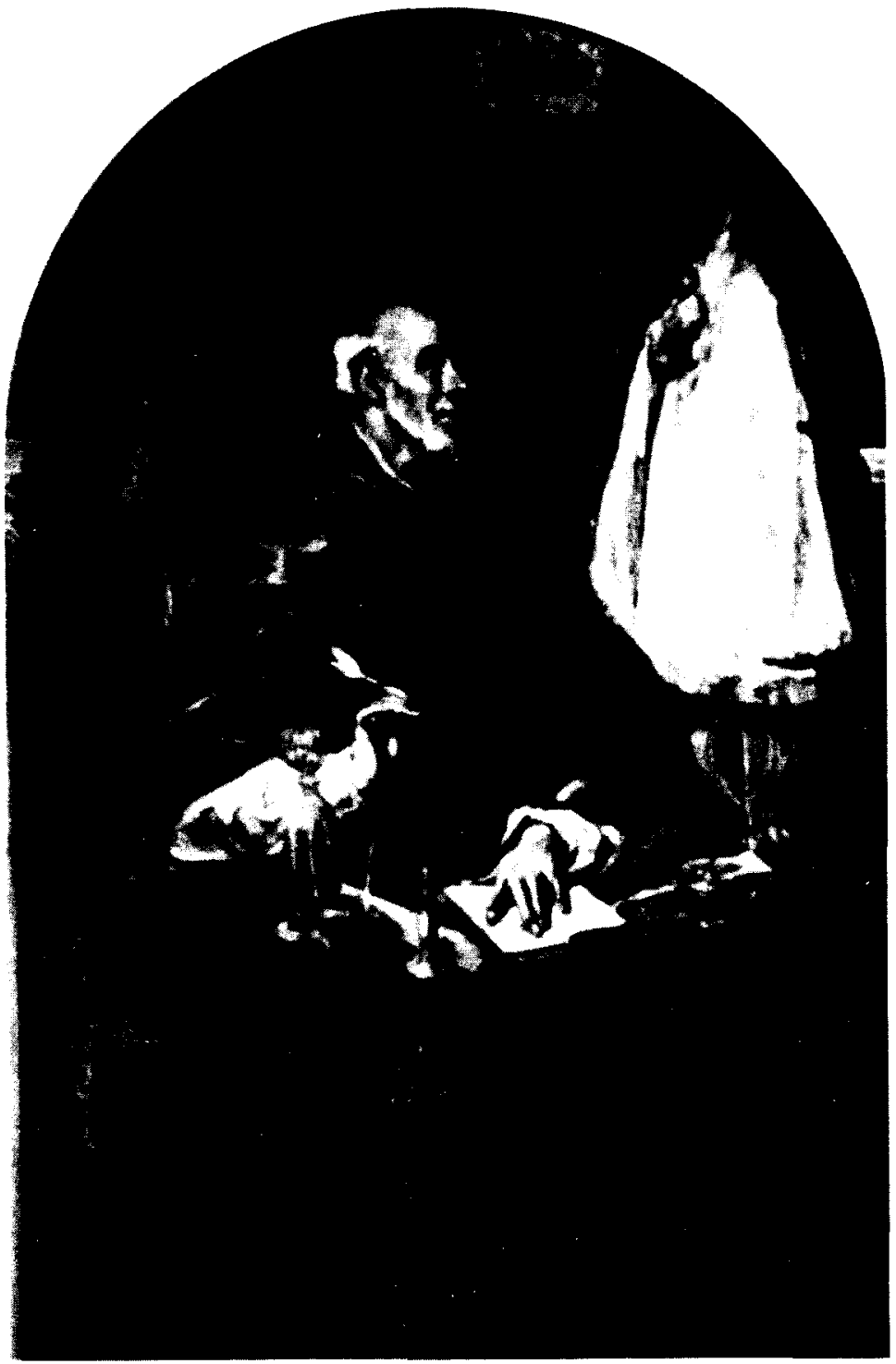

Fig. 7. "S. Ildefonso escribiendo". Hospital de la Caridad, Illescas (Toledo). 
La iconografía de la primera obra señalada es original. El Greco ha representado a S. Ildefonso escribiendo sobre la virginidad de María. Este matiz es el que convierte a la obra en contrarreformista, ya que es un tema defendido por la Iglesia católica, como se ha señalado, frente al protestantismo.

La imposición de la casulla a S. Ildefonso por parte de la Virgen, supondría la confirmación de que sus escritos son acertados y que por lo tanto los planteamientos de los protestantes son heréticos.

La segunda obra se podría interpretar en la misma línea. Aparece revestido de sacerdote, ésta podria ser la casulla que la Virgen le ha regalado y el libro, que sostiene, la obra que ha motivado el regalo. La autoridad eclesiástica de la que aparece investido simbolizaría la continuación de la otorgada por Cristo a los apóstoles.

\section{San Martín}

El cuadro de "S. Martín y el mendigo" se encuentra en Washington procedente de Toledo (fig. 8).

Existe una doble relación entre Martín Ramírez, fundador de la capilla de S. Jose, y su santo patrón: el nombre común a ambos y el tema del cuadro, la caridad, que fue practicada a través de la limosna por este hombre, según cuenta el epitafio de su tumba.

La escena representa una obra de caridad, virtud primada en la Iglesia católica según el texto de la I Carta a los Corintios $(13,13)$ de S. Pablo, que ya se ha comentado. Esta interpretación se enfrenta a la propugnada por el pensamiento reformista que señala a la fe, negando el valor de las obras.

\section{San Pedro}

Aparece en varios temas diferentes "Apostolado", "Lágrimas de $\mathrm{S}$. Pedro, "S. Pedro y S. Pablo" y "S. Pedro con llaves".

En todos aparece con su atributo más característico, las llaves.

Se le representa al Santo como primado de la Iglesia, cargo que le otorga Cristo (Mt. 16, 18-19) para presidir a los apóstoles y se confirma después de la Resurrección cuando Jesucristo le pregunta repetidamente si le ama y tras las respuestas le contesta "Apacienta mis ovejas" (Jn. 21, 15-17). Esta primacía es reconocida por los apóstoles y primeros cristianos en numerosos pasajes (Act. 1,$15 ; 2,14 ; 15,7$ ). 


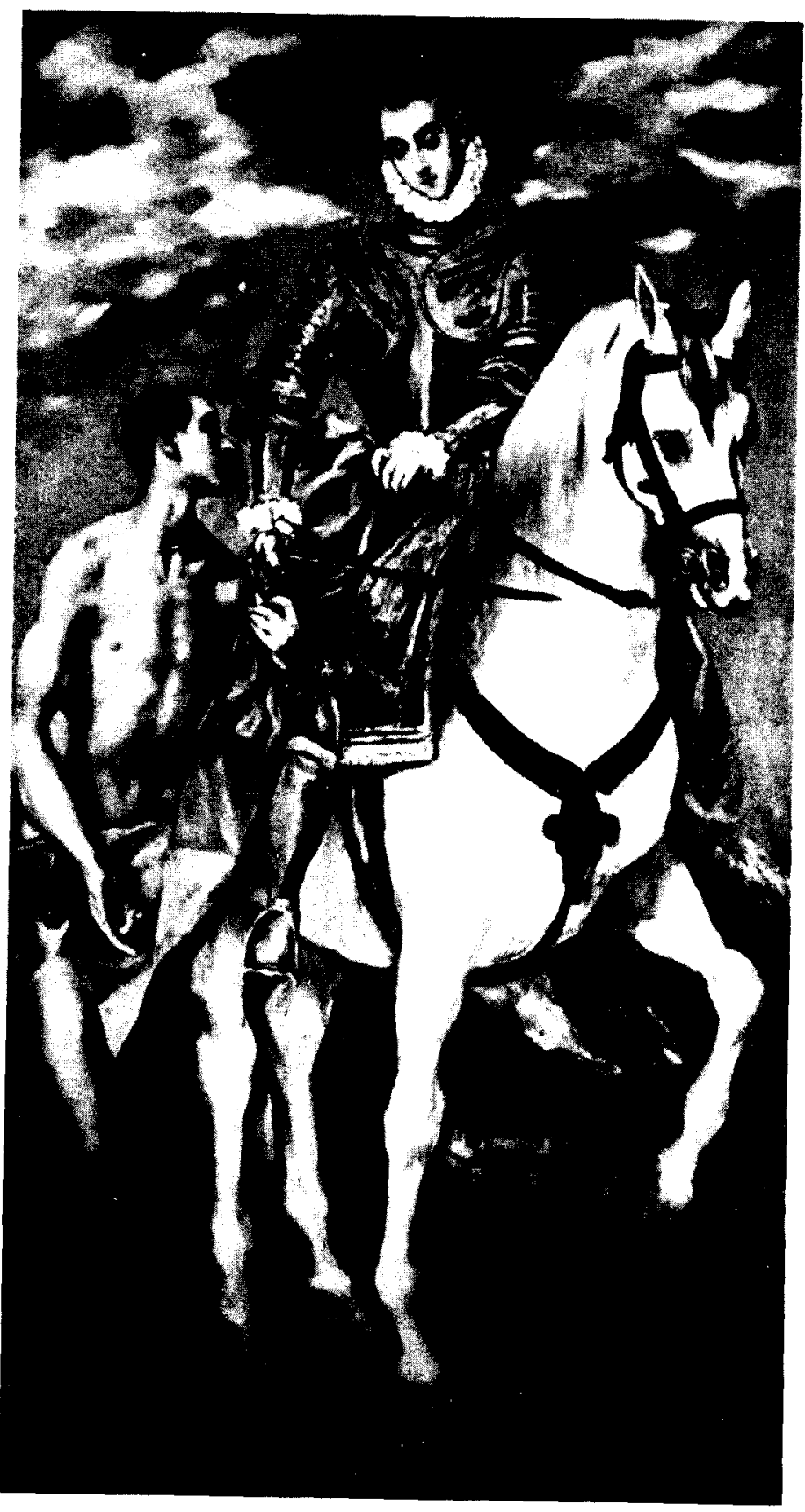

Fig. 8. "S. Martín y el mendigo" National Gallery, Washington. 
El protestantismo rechaza esta supremacía de Pedro sobre los demás apóstoles y especialmente que ésta supremacía sea transferible a otras personas a lo largo de la Historia.

La Iglesia católica interpreta que la supremacía de Pedro se transfiere a sus sucesores en el obispado de Roma, los papas. Esto lleva aparejado la potestad de fijar la doctrina critiana,... (Mt. 16, 19).

La primacía viene representada por las llaves según palabras textuales del Evangelio. También se interpreta que aquel que se separe de esta doctrina queda excluido de la salvación. En este sentido el protestantismo es una doctrina herética.

La figura de S. Pedro se revaloriza en el Concilio de Trento, precisamente por la negación que los protestantes hacen de que el Papa sea el sucesor de S. Pedro y que tenga la primacía sobre los demás obispos. Aspectos importantes que inciden en la jerarquía y estructura de ambas iglesias.

En el cuadro de "S. Pedro y S. Pablo" de Barcelona (fig. 9) esta idea se refuerza al apoyar S. Pablo su mano sobre la de S. Pedro, adquiriendo, éste último, la categoría de piedra sobre la que se asienta toda doctrina y creencia (Mt. 16, 18).

El gesto de S. Pablo también se puede interpretar como fidelidad a la persona de Pedro, que llegaría hasta el martirio (atributo de la espada).

En las versiones de Estocolmo y San Petersburgo, S. Pablo aparece con un libro en la mano, es decir como fundamento de la doctrina cristiana, que se consolidó en el Concilio de Trento de forma definitiva. No debemos olvidar que precisamente es el autor que señala la caridad como virtud primada (I Corintios 13, 13).

Las "Lágrimas de S. Pedro" (LC. 22, 62; Mc. 14, 72; Mt. 26, 75) es un tema del que existen numerosas versiones (fig. 10).

El cuadro recoge dos momentos y escenas distintas, que no ocurrieron al mismo tiempo ni en el mismo lugar, pero que están unidas por el mismo tema, el pecador arrepentido. Aparece Ma. Magdalena regresando del sepulcro después de haber conversado con el ángel y haber recibido la noticia de la Resurrección de Cristo (Mt. 28, 1-8; Mc. 16, 1-8; Lc. 24, 1-10; Jn. 20,1 y 11-13). San Pedro aparece en un lugar apartado, desierto, similar al de "Sta. Ma. Magdalena penitente", como lugar para la penitencia, para la preparación. Casos similares se recogen en diversos pasajes del Antiguo Testamento y algunos del Nuevo, caso de S. Juan Bautista y de Jesús, que se retira al desierto para prepararse a la vida pública (Mt. 4, 1-2). 


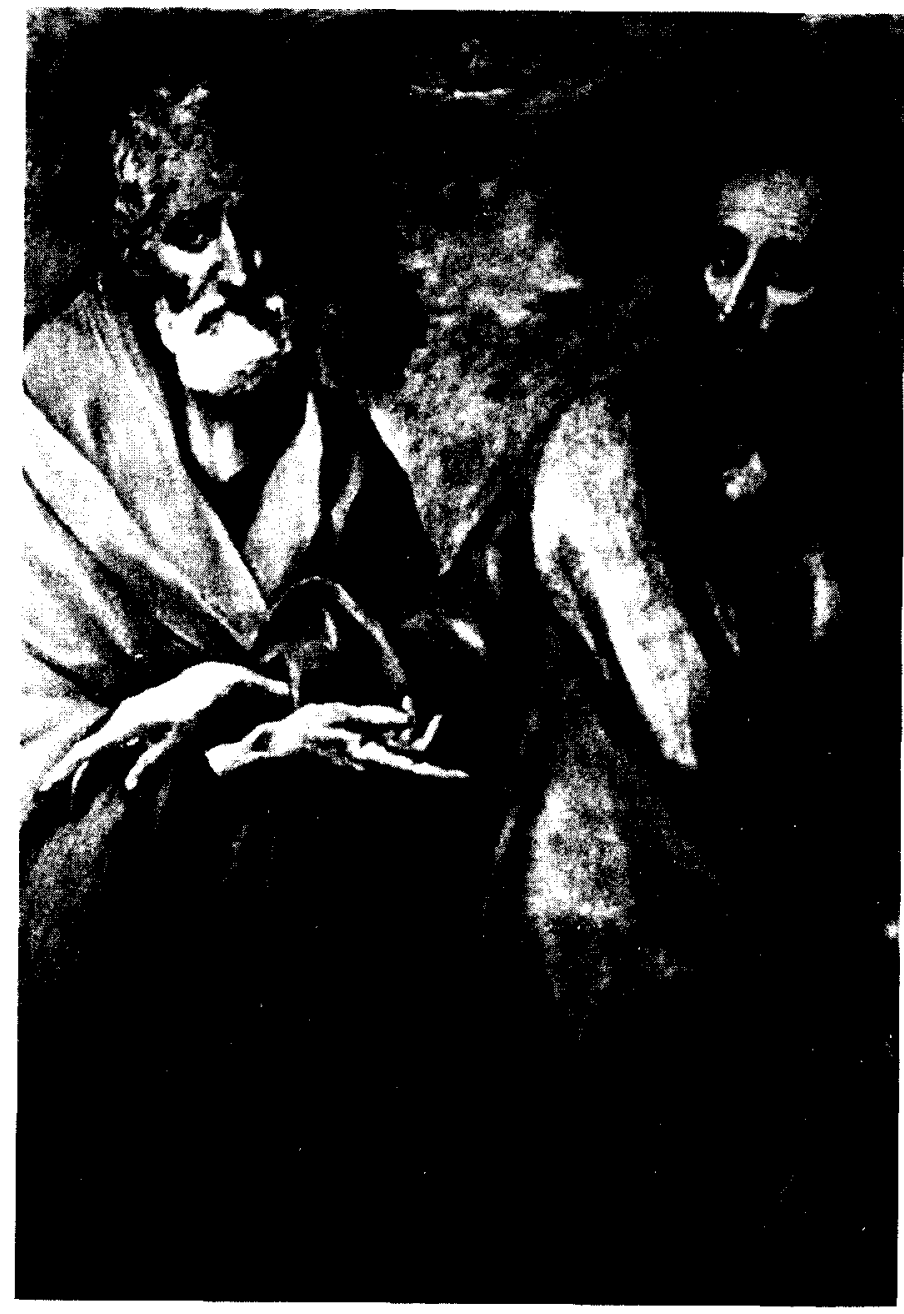

Fig. 9. "S. Pedro y S. Pablo" M. de Arte de Cataluña, Barcelona.

Las lágrimas son símbolo del arrepentimiento de S. Pedro, es decir se trata de una escenificación del sacramento de la penitencia, que es rechazado por la Reforma protestante y reafirmado por la Contrarreforma católica. Se afirma que el arrepentimiento y la confesión es el único camino para estar en gracia de Dios. Con ello se sostiene, en contra de los protestantes, que el pecado se borra y se ejemplifica en la persona del primero de los apóstoles, además su traición al juramento hecho al propio Cristo adquiere una carga trágica, pues El muere precisamente por los pecados de la 
Humanidad. El pecado de Pedro solo es redimido por la muerte de Cristo. A esto se une el dolor propio por el amigo abandonado en el momento en el que la amistad adquiere su valor real. El dolor está representado por medio de las lágrimas y las manos entrelazadas junto al corazón.

El pecado equivale a la muerte. La presencia del ángel en el sepulcro implica la resurrección y ésta es sinónimo de vida, de perdón de los pecados. Hasta tal punto esto es verdad para los católicos, que Cristo confirma a Pedro en la primacía de los apóstoles (Jn. 21, 15-17).

La institución de la penitencia como sacramento la realiza Cristo y la otorga a Pedro y los demás apóstoles (Mt. 16, 19; 18, 18; Jn. 20, 22). El

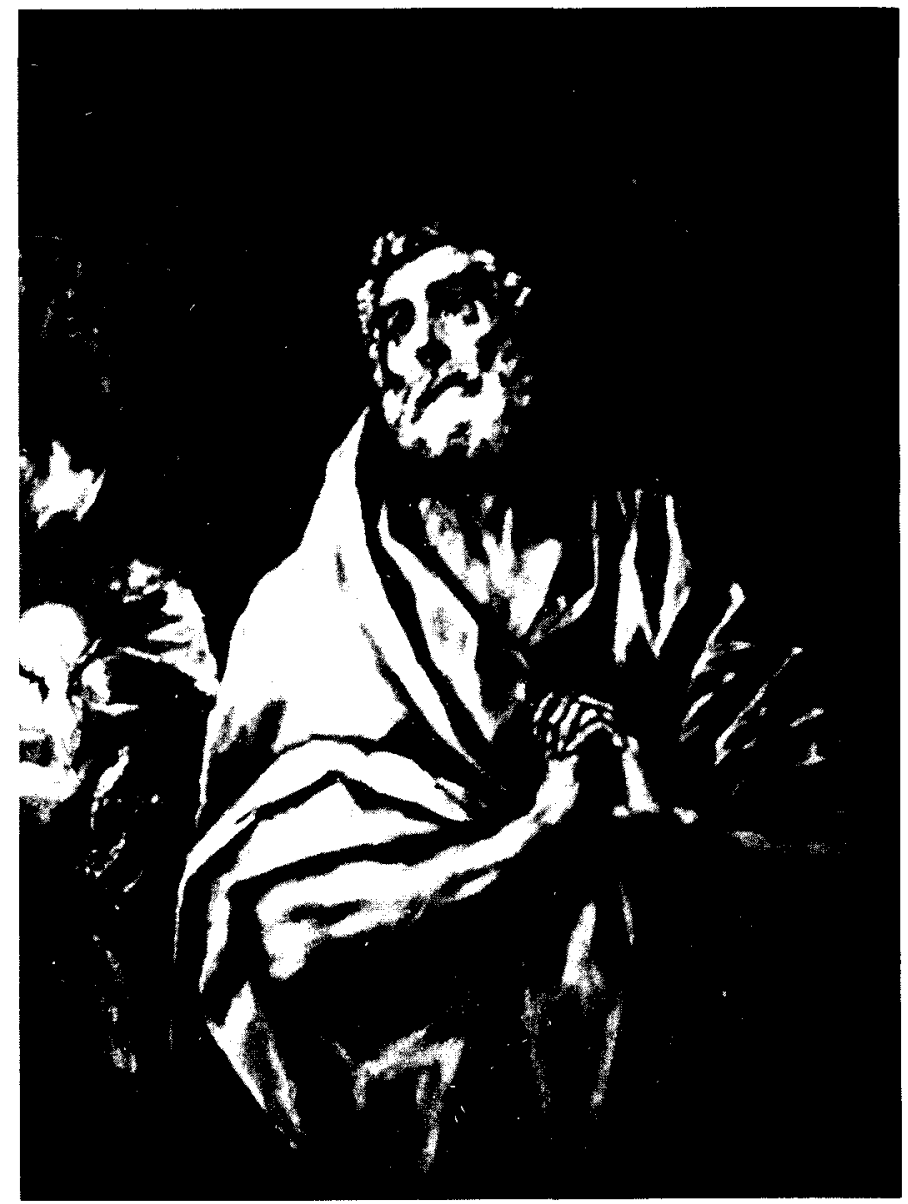

Fig. 10. "Lágrimas de S. Pedro" Nasjonalgalleriet, Oslo. 
primado de los apóstoles se convierte en modelo para todos los cristianos y se cumplen en él lo escrito por S. Pablo en la II Carta a los Corintios (5, 11-12) donde afirma que el perdón alcanzado tiene como fin que vivamos para aquel que murió y resucitó por nosotros.

\section{Santa Maria Magdalena}

Se conservan varios ejemplares en Estados Unidos (11), Hungría y España.

Su iconografía tiene un mensaje similar al de las "Lágrimas de $\mathrm{S}$. Pedro".

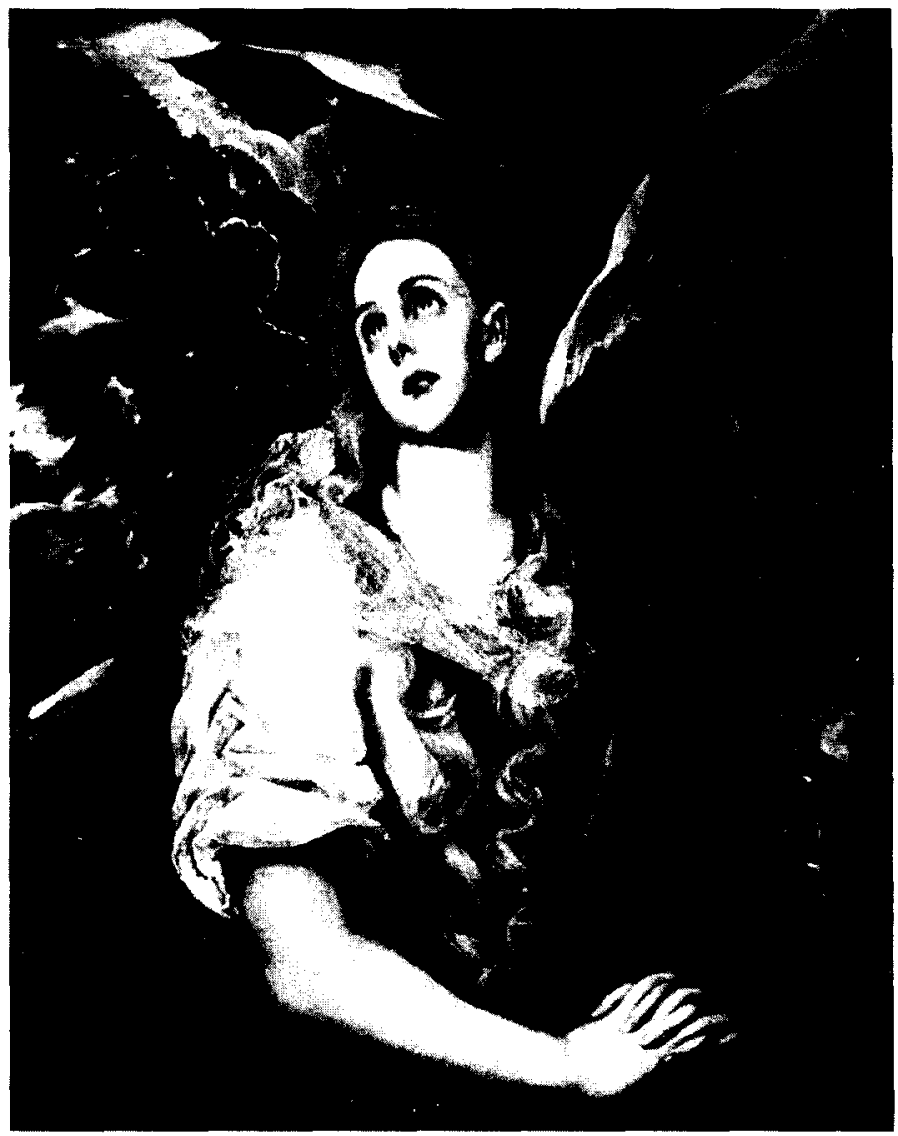

Fig. 11. "Sta. M. ${ }^{a}$ Magdalena penitente" Nelson Gallery-The Atkins Museum, Kansas City. 
La Santa aparece en un escenario deshabitado en el cual, según la tradición, llevó una vida de penitencia, convirtiéndose en la primera eremita de la Iglesia católica. Se la ha identificado con la pecadora que arrepentida derrama un frasco de perfume sobre Cristo. La misma que permanece junto a El mientras su hermana Marta se afana en las cosas de la casa. Este hecho sería el precedente de su posterior retiro y de la vida contemplativa.

Este tema fue frecuente en el arte y el Concilio de Trento lo realzó para afirmar que el arrepentimiento seguido de la confesión borra los pecados cometidos. María Magdalena se convierte en modelo a imitar por los cristianos, al igual que S. Pedro.

El aspecto de la confesión es rechazado por la Reforma protestante como ya se ha indicado más arriba. Aquí habría que añadir el tema de la vida contemplativa que lleva implícito el del celibato, igualmente rechazado por los protestantes, pues no existen órdenes religiosas y los sacerdotes contraen matrimonio.

Estos aspectos son ensalzados por la Contrarreforma. Parten de la tradición, pues Cristo no impuso el celibato a sus apóstoles, muchos de ellos estaban casados,pero con el paso del tiempo la Iglesia obligó a los sacerdotes y demás cargos, al voto de celibato. La vida contemplativa surje con fuerza en el mundo romano, cuando el cristianismo se convierte en religión oficial del Estado. La falta de sinceridad de las conversiones masivas estimuló la huida de algunos hacia lugares apartados.

\section{San Mauricio}

El "Martirio de S. Mauricio y la Legión Tebana" se conserva en el monasterio de El Escorial (Madrid) (fig. 12).

La obra narra la historia de S. Mauricio y la legión Tebana, que da su vida antes de renunciar a la fe en Cristo. El martirio es el tema principal de la obra, aunque esté desplazado a un segundo plano.

El tema se convierte en contrarreformista por dos vias diferentes: primero, por la época histórica en que se pinta, pues las guerras motivadas por las creencias religiosas son frecuentes. Segundo, por la obra en sí misma.

El martirio es el acto más sublime de sacrificio que un cristiano puede llevar a cabo por amor a Dios. En la aceptación de la muerte están conte- 


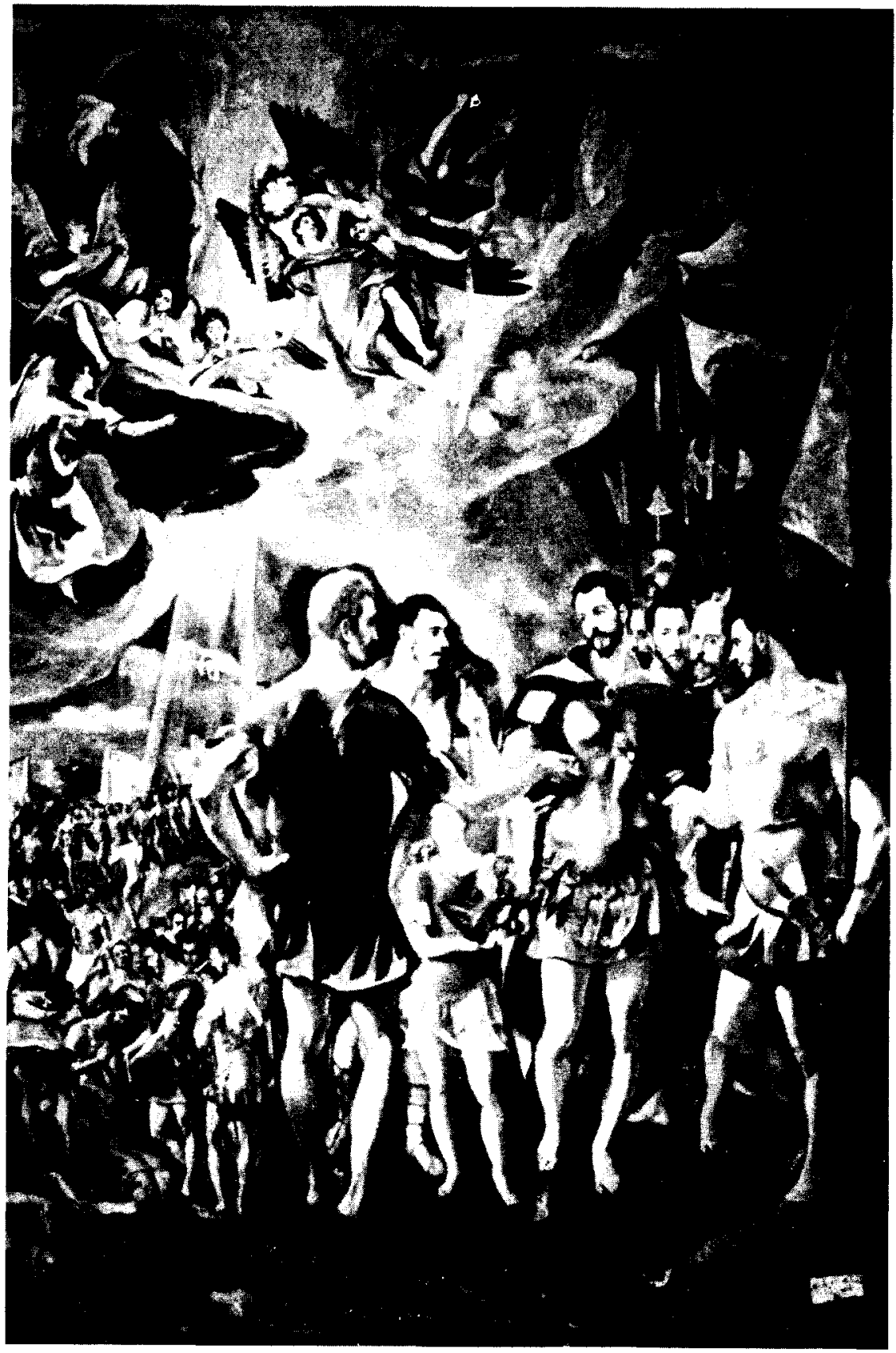

Fig. 12. El "Martirio de S. Mauricio y la Legión Tebana", Monasterio de El Escorial (Madrid). 
nidas en grado máximo las tres virtudes teologales: la fe, la esperanza y la caridad.

El martirio como acto de amor borra cualquier falta cometida. Presupone la muerte del mismo Cristo y su resurrección. De ahí la alegría que se produce en el cielo.

Quienes son protagonistas pasan a ser descritos por S. Juan Evangelista en el Quinto sello del Apocalipsis (6, 9-11). Hay una relación directa entre las reliquias que se depositan en el altar y el argumento del cuadro que lo preside.

La obra recuerda hasta donde debe llegar el cristiano en su fidelidad a la Iglesia de Roma en un momento de persecuciones religiosas protestantes (herejes). Al mismo tiempo los mártires del siglo XVI actualizan el martirio que los primeros cristianos sufrieron a manos de los paganos (herejes). Por la misma razón los mártires del siglo XVI recibirán similar premio que aquellos. El recuerdo de la justicia de Cristo supone una amenaza para todos aquellos que no sean capaces de llegar al martirio o que causan el mismo por haberse alejado de la Iglesia y convertido en perseguidores de la misma. 
